\title{
Persuasion in Romans 5:12-21
}

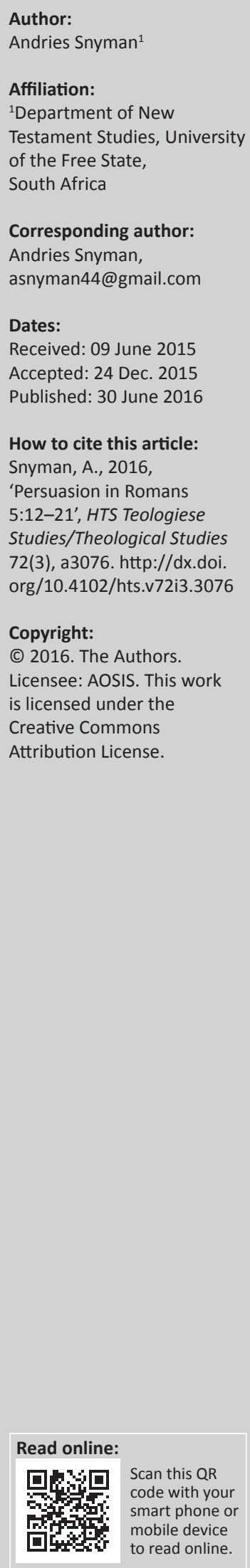

This article is an attempt to reconstruct Paul's rhetorical strategy from the text itself, rather than applying ancient or modern rhetorical models to his letters. A proposal for such a rhetorical approach is briefly summarised, followed by a discussion of the rhetorical situation of the letter. It is argued that the pericope, Romans 5:12-21, forms an integral part of Paul's rhetorical strategy, aimed at persuading his audience in Rome to share his views on the contrast between Adam and Christ: Adam's sin brought death into the world, but faith in Christ brings eternal life. In the process of persuasion, Paul uses various types of argument and rhetorical techniques to enhance the impact of his communication. To analyse and describe this is the main aim of the article. The conclusion is that a text-centred approach (with its focus on the functional aspects of the text) provides a meaningful alternative to existing approaches (which focus mainly on the formal aspects of the text).

\section{Introduction}

On Romans 5:12-21, Ben Witherington (2004:145) remarks: 'Here we are dealing with some of the most difficult material in all of Romans in terms of grammar and interpretation'. Exegetes such as Reid (1996:117) and Jewett (2007:370) share this view. The problems start forthwith with the question about whether verse 12 is an anacolouthon or not. Earlier translations regard it as an incomplete sentence, whereas recent ones tend to differ in interpretation. The line of thought in the pericope is further complicated by interruption, repetition and extended or less extended chiasms, leading to differences in demarcation of paragraphs and interpretation. All these factors impede upon the exegesis of Romans 5:12-21 - an exercise that is a prerequisite for any thorough rhetorical analysis.

Paul's use of rhetorical means in Romans has received due attention over the years. Studies on the subject were characterised mainly by two approaches. The first was to apply an external model to the text in order to describe its rhetorical structure. Nearly all of Paul's letters have been analysed, using the Greek-Roman rhetorical system with its well-known exordium, propositio, narratio, probatio and peroratio. In the second approach, rhetoric has been restricted to the identification of a few stylistic devices such as parallelisms, rhetorical questions, chiasms, and wordplays. Sporadic remarks on these devices are usually found in commentaries, without a description of their persuasive functions.

In contrast with these approaches, rhetorical analysis in this article is understood as a description of all the means in the text that the author uses to persuade his audience. A proposal for such a text-centred approach is Francois Tolmie's dissertation Persuading the Galatians (2005), published in the WUNT 2 series. The article begins with a summary of his proposal, followed by a description of the rhetorical situation and a detailed analysis of Romans 5:12-21, in which the focus is on the functions of the rhetorical means identified in the text.

The overall purpose is to prove that Paul's rhetorical strategy in the letter can be reconstructed fairly accurately from the text itself, without applying external ancient or modern categories.

\section{A text-centred approach to rhetorical analysis}

As it is impossible to analyse a text in a totally objective manner, Tolmie formulates what is called a 'minimal theoretical framework' in order to guide the analysis. He emphasises that this should not be used as a 'fixed methodology that could be applied rigorously to the text, but as a general guideline'. This could be summarised as follows (Tolmie 2005:28-29):

- A description of the rhetorical situation or context of the letter, that is, what Paul wants to achieve in the letter as a whole.

- A descriptive analysis of how he tries to persuade his audience, consisting of the following aspects: the identification of the dominant rhetorical strategy in each section by describing its 
primary rhetorical objective and determining how he attempts to achieve it. In this process, the focus is on the way in which he argues and the types of argument he uses to persuade his audience.

- The identification and description of the so-called rhetorical techniques, which serve to enhance the impact of his communication (see Snyman 2009:131).

Exegetical issues are discussed, especially when there is no agreement on the meaning of a specific phrase or expression. The focus, however, is on the rhetorical function, not on the issue as such.

\section{The rhetorical situation}

As point of departure, it is assumed that Paul wants to persuade the Romans about a matter of importance for himself and his audience. To understand the process, scholars use the notion of the rhetorical situation, which is not the same as the historical situation. Following Bitzer (1968:1-4), Kennedy (1984:35) defines it as 'a complex of persons, events, objects and relations presenting an actual or potential exigence'. For him, the writer must imagine the actual audience in order to construct the proper rhetorical response that will convince his audience. In particular, the writer must grasp the 'actual' rhetorical problem, that crucial issue which must be resolved, in order to persuade the audience to accept the writer's perspective.

Stamps (1993) and Vorster (1994) differ from this interpretation and regard the rhetorical situation as the situation embedded in, and created by the text - as Stamps (1993:200) explains: 'Rhetorically speaking, the sender constructs and presents his or her view of the situation in the epistolary text which the audience consents to for the sake of the argument'. This leads Vorster (1994:142) to the conclusion: 'The point of departure for the determination of the rhetorical situation need not be the historical circumstances, but should rather be the "entextualised" situation".

What, then, can we learn from the text with regard to the rhetorical situation? Firstly, the letter can be regarded as a broad account of the Gospel that Paul preaches, in light of the different contradictory views amongst the house churches in Rome. Most important amongst these were God's justice, the

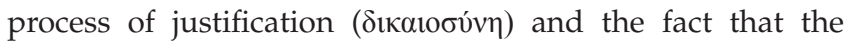
Jewish people rejected Jesus as the Messiah. Such issues questioned the legitimacy of the Gospel, as well as Paul's own credibility. The above becomes evident from the discussion of God's plan of salvation and the future of the Jewish people, who still regarded observance of the Mosaic

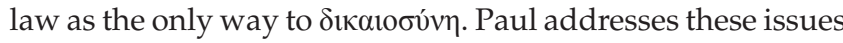
in his letter, and attempts to build a positive relationship with his fellow believers in Rome. He does so by focusing on the core of the message that he has been called to proclaim, namely that God absolves all people (Jews and non-Jews) from sin when they accept this message in faith.

In the letter, Paul explains the core of his message in different ways. In Romans 5:12-21, it is explained by comparing Adam with Christ: Adam sinned and this was how death entered the world. However, it was not the law, but Christ who gave his life for this purpose eliminated what Adam did. Christ's death not only cancelled the harm caused by Adam's fall, but surpasses it by far. With accounts such as these, Paul wants to persuade his audience of both the legitimacy of the Gospel and his own credibility.

Secondly, Paul is about to proclaim the Gospel in the West (Spain). For this reason, he needs the support of the believers in Rome (Rm 15:23-24) and, in order to obtain this, he must persuade them of both the legitimacy of the Gospel and his own true intentions. If they could associate with him and his message, they would support him on his journey to Spain and, thus, contribute to the completion of his worldwide mission. His Gospel is indeed worth proclaiming to all people on earth and his audience needs to be persuaded of this truth.

\section{Romans 5:12-21 Demarcation}

Before discussing Paul's persuasive strategy in detail, it is necessary to address the way in which this pericope has been demarcated by scholars who apply categories from the Graeco-Roman rhetorical tradition to the text, as well as the way in which it has been demarcated in this study, that is, from a text-centred perspective.

Scholars, who prefer to use the Graeco-Roman rhetorical system to analyse Paul's letters, usually define Romans 5:12-21 as part of the probatio of the letter. However, they differ considerably about its demarcation. According to Jewett (2007:viii-ix), in the letter of Romans the following divisions are identified:

- the exordium (1:1-12)

- the narratio (1:13-15)

- the propositio (1:16-17)

- the probatio $(1: 18-15: 13)$

- the peroratio $(15: 14-16: 24)$.

Talbert (2002:14) has the same division, whereas Reid (1995:117-139) divides the letter into the following categories:

- the exordium (1:8-15)

- the transitus (1:16-17)

- the narratio $(1: 18-3: 20)$

- the propositio $(3: 21-31)$

- the probatio (4:1-11:36)

- the paraenesis $(12: 1-15: 13)$

- the peroratio (15:14-33).

Chapter 16 is not regarded as part of the rhetorical structure. For Witherington (2004:21-22), the letter as a whole is divided into the following categories:

- the letter opening and greetings (1:1-7)

- the exordium (1:8-10)

- the narratio (1:11-15)

- the propositio (1:16-17)

- the probatio (1:18-8:39, consisting of eight arguments) 
- the refutatio (9:1-15:13, with four arguments)

- the peroratio (15:14-21)

- in addition, a few announcements on Paul's travel plans, concluded by epistolary greetings and a final benediction (15:22-16:27).

This wide variety of divisions, using the same rhetorical system, leads to serious doubt about the theoretical justification for employing categories of classical rhetoric to Paul's letters. For this reason, I prefer - in line with Tolmie and others - a text-centred approach, where the text itself serves as the starting point of analysis.

In this article, Romans 5:12-21 is demarcated by the following considerations. The pericope begins with the discourse

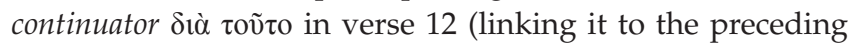
argument in Rm. 5:1-11) and closes with the Christological clausula 'through Jesus Christ, our Lord' (Rm. 5:21). A new pericope commences in Romans 6:1, with the rhetorical question in the first person plural: 'What then shall we say?' The last time Paul used the first person plural was at the end of the previous pericope ( $\mathrm{Rm} .5: 11)$ and this fact also demarcates Romans 5:12-21 as a unit for analysis. The antithesis between 'one' and 'many' continues through the pericope, thereby distinguishing it from the previous and following ones, whereas the frequent use of the argument $a$ minore ad maius and the rhetorical technique of repetition further strengthen the demarcation. As far as content is concerned, the comparison between two historical figures, representing the theme of death and life, is typical of 5:12-21 and is not found in 5:1-11 and 6:1-14.

The dominant rhetorical strategy in the pericope is to persuade the audience that Christ, who now rules over all who believe in Him, has broken the reign of death. The gist of the argument is not merely a comparison between Adam and Christ, but a focus on the effects of their respective deeds on mankind and the way in which Christ's act supersedes that of Adam. According to Hellholm (2006:8) and Jewett (2007:371), the pericope can be divided into four paragraphs: 12 (with a ๗блє $\rho$... oṽ $\omega \varsigma$ construction); 13-14 (dealing with the relation between law and sin); 15-17 (comparing Adam's transgression with God's gift of grace in Jesus Christ); and 18-21 (where the transgression of Adam and its consequences are compared with the results of Christ's obedience).

\section{Means of persuasion}

The following analysis commences with the broad lines of discourse to be found in most recognised commentaries, followed by the persuasive means used in the pericope.

The opening Siò $\tau o \tilde{\tau} \tau$ not only draws certain conclusions from the preceding argument in 5:1-11 (Cranfield 1975:271), but also serves as the marker of a new section, and that by way of the $\check{\sigma} \pi \epsilon \rho$... ovँ $\tau \varsigma$ construction: 'On account of this

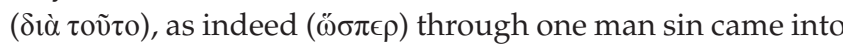
the world, and through sin death, and thus (oṽ $\omega \varsigma$ ) death has spread to all people, because everyone has sinned'. I agree with recent translations (such as the Good News Bible, as well as the 1983 and the new 2014 Afrikaans translations) that verse 12 is not an anacolouthon. The verse contains two important points of departure for the ensuing argumentation. Firstly, Adam's sin subjected all people, without exception, to the reign of sin and death. This is emphasised by the 'as ... thus' construction, in which 'thus' indicates the conclusion of the preceding two statements on the way in which sin has reached all men. If sin has entered the world in another way, it would have been a question about whether sin (and its resultant death) had reached all people. The fact is that sin came 'through one man' and in this way automatically, at once, reached all people. To his Roman audience, with their sharp distinctions between classes, this would have been a strange statement, with great impact. Secondly, 'death has spread to all people, because ( $\dot{\varepsilon} \phi$ ' $\tilde{\omega})$

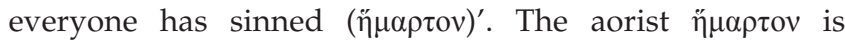

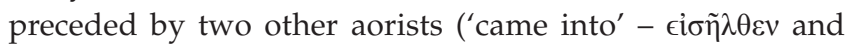
'has spread to' $-\delta 1 \eta \tilde{\lambda} \theta \varepsilon v)$, thereby describing historical facts that are indisputable. Against this background, the audience is prepared for the discussion of the contrast between death and life, which dominates the pericope.

In Romans 5:13-14, Paul abruptly introduces the law, and this in relation to sin: 'For prior to the law, sin was in the world, but $\sin$ is not recognised where the law does not exist. But death reigned from Adam to Moses, even over those who did not $\sin$ in the likeness of the transgression of Adam, who is a

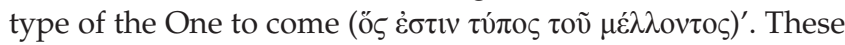
two verses still occupy the minds of exegetes. The first problem relates to the nature of sin that was committed in the period from Adam to Moses. It is most likely that this problem cannot be solved (cf. Jewett's discussion 2007:376-377). A second problem is the interpretation of the passive 'is (not)

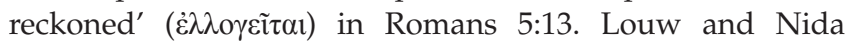

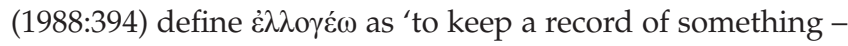
"to record, to list"'. In discussing this meaning, they point out that the term in Romans 5:13 cannot be regarded as a passivum divinum, because 'this might imply that God was unconcerned about $\sin ^{\prime}$. As a result, they propose the translation 'a sin is not listed as a sin'. This, however, does not solve the problem

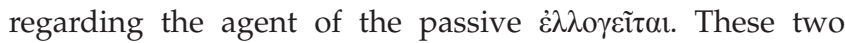
problems clearly illustrate and confirm Witherington's remark that our pericope contains 'some of the most difficult material in all of Romans in terms of grammar and interpretation'.

On the positive side, verses 13 and 14 include information that is very important for Paul's argumentation. Though we are not informed about the nature of $\sin$ in the period between Adam and Moses, the heart of the matter is that death did reign at that time. The verb $\beta \alpha \sigma i \lambda \varepsilon v i \omega$ can be defined as 'to be in control in an absolute manner - "to reign, to control completely"' (Louw and Nida 1988:474-475). In verse 14 , this refers to the dominion exercised by death as a cosmic power. In verses 12 and 21, the verb is also used for Christ's rule over his dominion. This occurs five times in the pericope, with the same meaning in each case. 
The most important statement in verses 13 and 14 is the

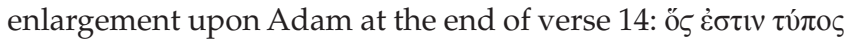

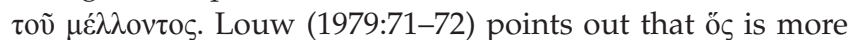
than an enlargement upon Adam; in fact, it serves as an introduction to the following paragraph and should be

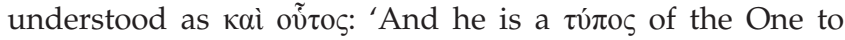

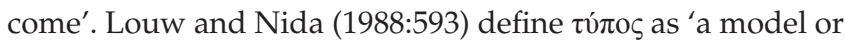
example which anticipates or precedes a later realization "archetype, figure, foreshadow, symbol"'. Adam is a foreshadow of Christ in the sense that he and his deed (as that of Christ) represent his subjects and determine their fate. Barrett (1962) states about this:

Paul sees history gathering at nodal points and crystalizing upon outstanding figures, who are notable in themselves as individual persons, but even more notable as representative figures. These incorporate the human race, or sections of it, within themselves, and the dealings they have with God they have representatively on behalf of their people. (p. 5)

The phrase 'who is a type of the One to come' is proof of the extent of the disaster that happened to mankind with the fall of Adam; nothing less than a deliverance prepared by God himself could rectify the damage caused by his fall. Adam had to resemble Christ: the One to come had to be a type of the archetype Adam in order to save all those who had fallen in sin. Thus, Adam's single transgression typifies Christ's single deed of redemption in a decisive way. The latter had to replace the former.

Though Adam resembles Christ, there is a difference. The difference is explained in verse 15:

For if by the trespass of one man, the many died, how much more ( $\pi \circ \lambda \lambda \tilde{\omega} \mu \tilde{\alpha} \lambda \lambda \mathrm{ov})$ did the grace of God and the gift by grace of the one person Jesus Christ abound for the many.

This clearly expresses the similarity and the difference between Adam and Christ. The similarity is: one man is the cause of $\sin$ and death, one man the source of grace. There are, however, considerable differences, not only between sin and death, on the one hand, and grace and life, on the other, but especially in the sense that the latter excels the former by far. In what sense this happened is not explained at this stage, because grace surpasses sin to such an extent that it needs to be explained step by step in the following verses. Verse 15 simply states the fact that grace did much more than merely repair the damage caused by Adam. The way in which Paul elaborates on the gift of grace in Christ (over and against the brief description of Adam's trespass and its consequences) is rhetorically significant: it echoes the abundance of God's grace in Christ. The two verbs in the past tense, namely 'died'

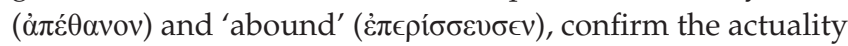
of the events.

The difference between type and antitype is taken a step further in verse 16, which is structurally equivalent to verse 15 :

And the gift is not like the sin by the one. For on the one hand the judgement from one (led) to condemnation, but on the other hand the grace gift from many trespasses (led) unto acquitting judgement.
There is no verb in the original Greek, but the trend of the argument is clear: although Adam resembles Christ, there is an important difference: Adam's sin brought the verdict

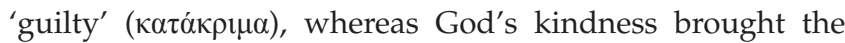

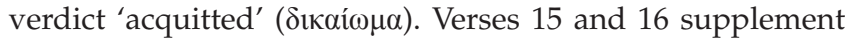
each other and stress the point that there is no comparison between the trespass of Adam and the grace gift of God in Jesus Christ. The content of these two verses is repeated in verse 17:

For if by the trespass of one, death reigned ( $\left.\dot{\beta} \beta \alpha \sigma^{\prime} \lambda \varepsilon v \sigma \varepsilon v\right)$ through that one, how much more $(\pi \circ \lambda \lambda \tilde{\omega} \mu \tilde{\alpha} \lambda \lambda \mathrm{ov})$ shall those receiving

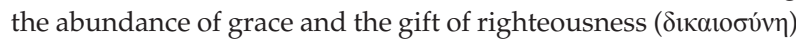
reign ( $\beta \alpha \sigma \lambda \lambda \varepsilon v ́ \sigma o v \sigma ı v)$ in life through the one, Jesus Christ.

As in verse 15, the abundance of God's grace in Christ is also emphasised by the long description thereof. The description highlights other differences with Adam: the reign of death was the result of the verdict 'guilty' and applies to all people, whilst the verdict 'acquitted' only refers to 'those receiving the abundance of grace and the gift of righteousness

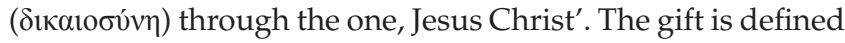

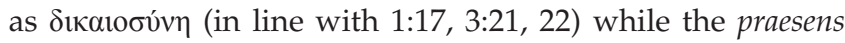
participium $\lambda \alpha \mu \beta \alpha$ óvoves ('receiving') is iterative: those who receive the gift continuously, one by one, through the ages, 'shall reign in life'. Herein lies the abundance of God's grace: death reigns through one ruler; believers shall reign as rulers 'in life' ( $\dot{\varepsilon} v \zeta \omega \tilde{n}$, placed in the original before the verb

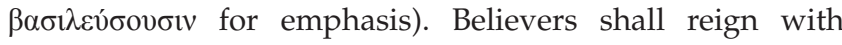
Christ: He being the King of kings, we as kings!

This is possible 'through the one, Jesus Christ', placed at the very end of verse 17 as the climax of Paul's argument: if death reigned through the one man, how much more shall those who received the abundance of God's grace, reign in life through Jesus Christ. The preposition sió indicates Him as

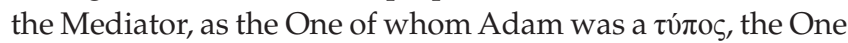
to come. The more death starts reigning, the more shall believers reign in life; and the more they had lost as a result of Adam's sin, the more they, who believe in Christ, shall receive.

In the final paragraph of his discourse on the contrast between death and life, Paul expands the notion further by

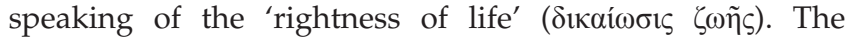
paragraph begins with the concluding oũv ('therefore') and the notion of $\delta$ iк $1 \omega \sigma \mathrm{s}$ links it to the central theme of the letter, namely righteousness through faith (Rm. 1:17). Adam's disobedience led to the condemnation of all people, but Christ's obedience settled the matter for everyone who believes in Him. He cleansed the slate and made it possible for everyone to be put right with God - something that was not possible prior to his death on the cross. In verse 19, Paul continues with the notion of disobedience versus obedience when he writes: 'For as through the disobedience of one person many were made sinners ( $\dot{\alpha} \mu \alpha \rho \tau \omega \lambda$ oì $\kappa \alpha \tau \varepsilon \sigma \tau \alpha \dot{\theta} \theta \eta \sigma \alpha \nu)$ so also through the obedience of one many shall be made

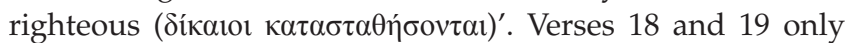
deal with the similarities between Adam and Christ, not the differences. The fact that the two statements in verse 19 are 
parallel in structure is of rhetorical importance, with both verbs in the passive: firstly, the aorist $\kappa \alpha \tau \varepsilon \sigma \tau \alpha \theta \eta \eta \sigma \alpha v$ and, secondly, the futurum $\kappa \alpha \tau \alpha \sigma \tau \alpha \theta \dot{\sigma} \sigma o v \tau \alpha 1$. (For the functions of these, see discussion below). There is no verb in verse 18 .

In 5:20, Paul returns to the law, which he refers to in verse 13, and regards it as a person who intruded into the historical process: 'But the law intruded in order that the trespasses

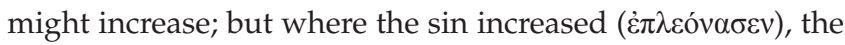
grace superabounded (i $\pi \varepsilon \rho \varepsilon \pi \varepsilon \rho i ́ \sigma \sigma \varepsilon v \sigma \varepsilon v)^{\prime}$. Both verbs are once more in the aorist, thus emphasising the actuality of the events. At the same time, they constitute the climax of the series of 'how much more' arguments in the pericope

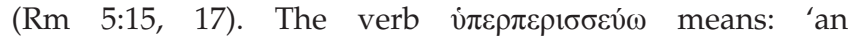
extraordinary degree, involving a considerable excess over what would be expected - "extreme, extremely, in an extreme degree, to a very great degree"' (Louw \& Nida 1988:689). They point out that the term might simply refer to quantity, but it is better to interpret it as expressing degree. In verse $5: 20$, the verb is an expression of the abundant degree

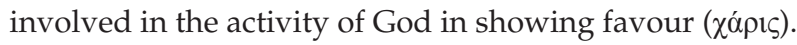

Verse 21 concludes the rhetorical comparison by comparing the effect of death that Adam brought into history with the effect of Christ's death. It is again a parallel construction (as the $\check{\sigma \pi \varepsilon \rho ~ . . . ~ o v ँ \tau \omega \varsigma ~ m a r k e r s ~ s u g g e s t) ~ t h a t ~ b e g i n s ~ w i t h ~ a ~}$ purpose clause:

in order that just as $(\ddot{\omega} \sigma \pi \varepsilon \rho)$ the sin reigned $(\dot{\varepsilon} \beta \alpha \sigma i \hat{\lambda} \varepsilon v \sigma \varepsilon v)$ in

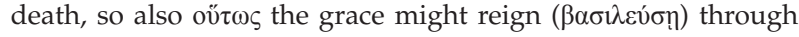

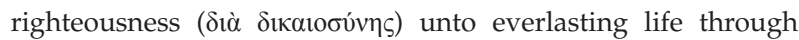

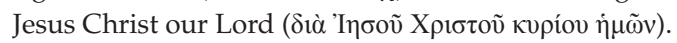

With the prepositional phrase at the end of the verse, Christ's mediatorship is finally proclaimed and emphasised. He is the One who puts an end to the reign of death and rules over everyone who believes in Him.

One of the most persuasive arguments that Paul uses in 5:12-21 is the well-known Jewish exegetical a minore ad maius type of argument. In 5:15, it is marked by

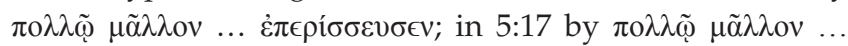
$\pi \varepsilon \rho 1 \sigma \sigma \varepsilon i \alpha v$, and in 5:20 by the strong verb $\dot{\pi} \pi \varepsilon \rho \varepsilon \pi \varepsilon \rho i ́ \sigma \sigma \varepsilon v \sigma \varepsilon v$ (preceded by غ̇ $\pi \lambda \varepsilon o ́ v \alpha \sigma \varepsilon v$ ). In this type of argumentation, one issue is dissociated from, and compared to another one, which has a more elevated purpose and supersedes it by far. For example, in 5:15 God's grace-gift in Christ is distinguished from, and compared to the trespass of Adam the logic being as follows: in order to understand and appreciate God's gift in Christ, one must understand the way in which Adam's trespass has affected humanity. If one grasps the latter, one can better appreciate the former. The function of the argument is to persuade the Romans that Christ's death on the cross has outdone the results of Adam's fall by far. This is also its function in 5:17 and 20: in which the attention of the audience is focused on the second part, the conclusion, which deals with the way in which Christ's death has affected humanity. The climax of this type of argument is in verse 21 , as pointed out earlier.
The argument a minore ad maius is embedded in what Witherington (2004:141-142) describes as 'the rhetoric of comparison'. He refers to Quintilian, who maintains that nearly all deliberative speeches are based on comparison (Inst. Or. 3.8.23-24) and that is the reason why Paul resorts to this type of argument in 5:12-21 (and, to a lesser degree, elsewhere in Rom., cf. chapters 2 and 3). In 5:12-21, however, Paul is not simply comparing Adam and Christ, but he is comparing the effects of what Adam did to mankind to the effects of what Christ did. Paul is emphasising the differences, as is clearly stated in 5:15: 'The trespass is not like the grace gift'. Thus the comparison in 5:12-21 is not between two historical persons or issues on the same level, but between One who is by far superior to the other in terms of their impact on mankind.

The third effective means of persuasion that Paul uses in this pericope is personification ( (2000:106) distinguishes between personification and $\pi \rho о \sigma \omega \pi$ олой $\alpha$, but finds no support. According to the majority of New Testament scholars (including Jewett 2007:625-627; Talbert 2002:185-186; Tolmie 2005:113-114; Wagner 2002:159-165; Witherington 2004:150-151), both terms refer to the same rhetorical means, whereby a concept is treated as a person performing a specific human action. In $5: 14$, death is presented as someone reigning from Adam to Moses; in verse 20, the law intruded into history as an actor on the stage; and in verse 21, grace might reign through righteousness, leading people to eternal life. The function of personification is to render a lively effect to the discourse. It was a powerful means of persuasion in ancient times and was so universal that Paul's audience would have easily understood it (Tobin 2004:343). According to Talbert (2002:186), it was part of the training of letter writers in the GraecoRoman world.

The comparison between Adam and Christ could also be regarded as an argument based on allegory. Two historical figures are discussed allegorically, where Adam represents the negative part, and Christ the positive. An allegory is a type of comparison, in which a person is presented as an image or likeness of a particular concept or issue. Such an argument based on allegory is a well-known and effective means of persuasion in Paul's letters. In the preceding chapter (4:1-25) he compared Abraham and the Christian believers by using an allegory: Abraham was an example of people who believed without being circumcised, whilst Christians also received God's promises through faith alone (Talbert 2002:150-151). In his letter to the Galatians, Paul uses his best-known allegory: Sarah and Hagar as representatives of two covenants, used to urge his audience not to yield to the opponents' 'Gospel' (Tolmie 2005:171-172). Similarly, Adam represents death in 5:12-21, whereas Christ represents life. The function of the allegorical argument is to persuade his audience of Christ's work of redemption that broke up the reign of death.

A final means of persuasion in 5:12-21 is an argument based on divine involvement. In verse 15, Paul refers explicitly to 
God's grace that came through Jesus Christ - a grace defined as 'the gift of righteousness' (verse 17). In the passive verbs

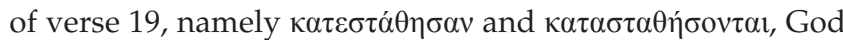
is also the One who acts: He made many to be sinners as a result of Adam's disobedience, just as He made many people righteous on account of Christ's obedience. These arguments based on God's involvement strengthen Paul's reasoning in the sense that they bind him and his audience to the One, who is authoritatively involved in the course of history and determines it in the last instance.

The rhetorical (stylistic) techniques in 5:12-21 are mainly figures of repetition at the levels of syntax, phrases, words and syllables:

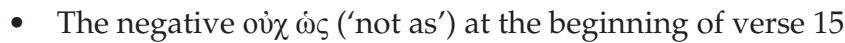
is repeated at the beginning of verse 16 . This technique is known as anaphora (Nida et al. 1983:178) and has an important function in this context: it draws attention to the difference between the transgression of Adam and the grace-gift in Christ, which is the core of the comparison in 5:12-21.

- The repetition of the syllable, $-\mu \alpha$ at the end of $\delta \omega \rho \eta \mu \alpha$

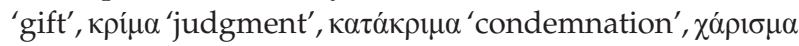
'grace-gift', and $\delta 1 \kappa \alpha i \omega \mu \alpha$ 'righteous act', in 5:16 is technically called homoioteleuton (Nida et al. 1983:176-177) and serves to link the deeds and their consequences.

- The repetition of the same syllables at the beginning and

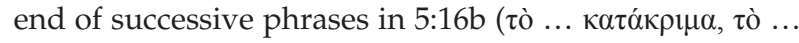
$\delta 1 \kappa \alpha i \omega \mu \alpha)$ serves the same purpose and is technically known as symploke (Nida et al. 1983:175).

- The antithetic parallelism in 5:18 (literally translated: 'as through one trespass to all people came condemnation, so through one act of setting right to all people came the rightness of life') is used to emphasise the notion of 'through one' versus 'all people'. An antithetic parallelism has a parallel structure, with opposite meaning. The same technique is repeated in verse 19.

- The $\check{\sigma} \pi \varepsilon \rho / \dot{\omega} \varsigma$... oṽ $\omega \varsigma$ ('just as ... so also') construction in verses 18, 19 and 21 is used to draw comparisons between Adam and Christ - with the focus on the oṽ $\omega \varsigma$ (concluding) parts, in order to emphasise the eminence of Christ's work of redemption.

- Chiasm is also a form of repetition, defined by Nida et al. (1983:178) as inverted parallelism. This well-known technique is to be found in 5:21: $\dot{\varepsilon} \beta \alpha \sigma i ́ \lambda \varepsilon v \sigma \varepsilon v$ (verb) -

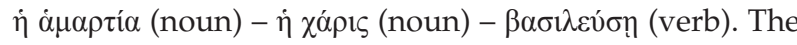
words that are repeated are key concepts in verse 21 and by using chiasm the attention of the audience is focused more directly on the content of what is said, thereby neatly and effectively summarising the core of Paul's argumentation in 5:12-21.

\section{Conclusion}

The finding of this study is that Tolmie's proposal for a textcentred rhetorical analysis of Paul's letters provides a meaningful alternative to the existing approaches. Instead of forcing a model from outside upon the text or regarding only a few stylistic devices as rhetoric, an attempt was made to identify all the means of persuasion in 5:12-21 and to describe their functions in context.

In the article, Romans 5:12-21 is demarcated by (mainly) rhetorical considerations and divided into four paragraphs: $12,13-14,15-17$, and 18-21. The focus is on the types of argument Paul uses and the rhetorical techniques supporting his communication. An argument frequently used is the wellknown a minore ad maius. He also uses arguments based on comparison, on divine involvement and on allegory, whilst personification serves to render a lively effect to the discourse.

As far as rhetorical techniques are concerned, Paul uses various forms of repetition to strengthen his communication in order to persuade his audience that Christ, who rules over everyone that believes in Him, has broken the reign of death.

\section{Acknowledgements Competing interests}

The author confirms that he has no financial or personal relationships which may have inappropriately influenced him in writing this article.

\section{References}

Anderson, R.D., 2000, Glossary of greek rhetorical terms connected to methods of argumentation, figures and tropes from Anaximenes to Quintilian, Peeters, Leuven. (CBET 24)

Barrett, C.K., 1962, From first adam to last, Black, London.

Bitzer, L.F., 1968, 'The rhetorical situation', Philosophy and Rhetoric 1, 1-14.

Cranfield, C.E.B., 1975-1979, A critical and exegetical commentary on the epistle to the Romans, 2 vol. 1, ICC, Clark, Edinburgh.

Hellholm, D., 2006, 'Universalität und Partikularität. Die amplifikatorische struktur von Rom 5:12-21', in D. Sänger \& U. Mell (eds.), Johannes und Paulus, pp. 1-24, WUNT, Mohr-Siebeck, Tübingen.

Jewett, R., 2007, Romans. A commentary, Fortress Press, Minneapolis, MN.

Kennedy, G.A., 1984, New Testament Interpretation through Rhetorical Criticism University of North Carolina Press, Chapel Hill.

Louw, J.P., 1979, A semantic discourse analysis of Romans, Vol. 2, University of Pretoria Press, Pretoria.

Louw, J.P. \& Nida, E.A., 1988, Greek-English lexicon of the new testament based on semantic domains, vol. 2, United Bible Societies, New York.

Nida, E.A., Louw, J.P., Snyman, A.H. \& Cronje, J. v. W., 1983, Style and discourse, Bible Society of South Africa, Goodwood.

Reid, M., 1995, 'Paul's Rhetoric and Mutuality: A rhetorical reading of Romans', in SBL Seminar Papers, pp. 117-139, Scholars Press, Atlanta, GA.

Reid, M.L., 1996, Augustinian and pauline rhetoric in Romans five: A study of early Christian Rhetoric, MBPS 30, Mellin, Lewiston, ME.

Snyman, A.H., 2009, '1 Corinthians 1:18-31 from a rhetorical perspective', Acta Theologica 29(1), 130-144.

Stamps, D.L., 1993, 'Rethinking the rhetorical: The entextualization of the situation in new testament epistles', in S.E. Porter \& T.H. Olbricht (eds.), Rhetoric and the new testament: Essays from the 1992 Heidelberg Conference, pp. 193-210, JSNTSup 90, JSOT Press, Sheffield.

Talbert, C., 2002, Romans, Smyth and Helwys, Macon.

Tobin, T.H., 2004, Paul's rhetoric in its context: The argument of Romans, Hendrickson, Peabody, MA.

Tolmie, D.F., 2005, Persuading the Galatians. A text-centred rhetorical analysis of a Pauline letter, Mohr-Siebeck, Tübingen. (WUNT 2/9)

Vorster, J.N., 1994, 'The context of the letter to the Romans: A critique on the present state of research', Neotestamentica 28, 127-145.

Wagner, J.R., 2002, Heralds of the good news: Israel and Paul 'in concert' in the letter to the Romans, Brill, Leiden. (NovTSup 101)

Witherington, B., 2004, Paul's letter to the Romans. A Socio-Rhetorical commentary, Eerdmans Publishing Company, Grand Rapids, MI. 